\title{
Trivaric Acid, a Potent Depside Human Leukocyte Elastase Inhibitor
}

\author{
Zhihui Zheng, ${ }^{a, \#}$ Shen Zhang, ${ }^{b, \#}$ Xinhua Lu, ${ }^{* a}$ Ying Ma,${ }^{a}$ Yuling Fan, ${ }^{a}$ Ying Shi, ${ }^{a}$ \\ Aihua Dong, ${ }^{* a}$ and Baoling Duan ${ }^{a}$ \\ ${ }^{a}$ New Drug Research \& Development Center, North China Pharmaceutical Group Corporation; No. 388 Heping \\ East Road, Shijiazhuang 050015, Hebei, China: and ${ }^{b}$ College of Life Science, Sichuan University; Wangjiang Road, \\ Chengdu 610064, Sichuan, China.
}

Received July 22, 2012; accepted September 7, 2012; advance publication released online September 25, 2012

Human leukocyte elastase (HLE) is a serine protease implicated in several inflammatory diseases, and represents a major target for anti-inflammatory drug development. In the present study, nordivaricatic acid (1), divarinyl divarate (2), and trivaric acid (3), three depsides isolated from the culture of a soil derived fungal strain were identified as inhibitors of HLE. Two didepsides 1 and 2 showed low inhibitory activity. In contrast, trivaric acid, a para-tridepside, exhibited highly potent inhibitory activity with an $\mathrm{IC}_{50}$ value of $1.8 \mu \mathrm{M}$ and a $K_{\mathrm{i}}$ of $0.6 \mu \mathrm{M}$. Kinetic investigations with trivaric acid showed that this inhibition is reversible, competitive pattern. Further studies on the selectivity of three depsides toward serine proteases showed that they did not inhibit chymotrypsin, trypsin and thrombin even at $150 \mu \mathrm{M}$.

Key words human leukocyte elastase; depside; trivaric acid; fungus

Human leukocyte elastase (HLE, EC 3.4.21.37), also known as human neutrophil elastase (HNE) and human granulocyte elastase, is a member of the chymotrypsin superfamily of serine proteases, and highly expressed in the azurophilic granules of polymorphonuclear leukocytes (PMNLs). HLE can very efficiently degrade tissue matrix proteins such as elastin, collagen, fibronectin, laminin and proteoglycan by activating procollagenase, prostromelysin, and progelatinase, and is potentially one of the most destructive enzymes in the body. ${ }^{1)}$ Under physiological conditions, HLE is released from PMNLs because of inflammatory stimuli and mediators, and is inactivated by a number of endogenous proteinase inhibitors such as $\alpha_{2}$-antiplasmin, $\alpha_{1}$-antichymotrypsin, antithrombin, and tissue inhibitor of metalloproteinases. ${ }^{2,3)}$ The imbalance between HLE and its endogenous inhibitors leads to abnormal tissue destruction which is associated with a number of inflammatory diseases including pulmonary emphysema, ${ }^{4)}$ adult respiratory distress syndrome (ARDS) ${ }^{5)}$ chronic bronchitis, ${ }^{6}$ chronic obstructive pulmonary disease (COPD), ${ }^{7,8)}$ rheumatoid arthritis (RA) ${ }^{9)}$ and acute lung injury (ALI). ${ }^{10)}$ In addition, HLE plays an important role in invasion and metastasis of human breast and lung cancer. ${ }^{11)}$ Hence, HLE has been an important therapeutic target.

Research and development of potent small molecular HLE inhibitors has been conducted for over three decades worldwide, and a number of synthetic and natural inhibitors have been discovered and evaluated biologically both in vitro and in vivo. ${ }^{12,13)}$ The most advanced synthetic inhibitor is ONO-5046 (sivelestat) which has been launched in Japan (2002) as an injectable formulation for the treatment of acute lung injury associated with systemic inflammatory response syndrome, ARDS and ALI. ${ }^{14,15)}$ MR-889 (midesteine), an irreversible HNE inhibitor, is also in pre-registration for the treatment of COPD in Italy. ${ }^{16}$

In our searching for novel HLE inhbitors from natural or synthetic compounds, three depsides from the culture of a soil derived fungal strain were identified as inhibitors of HLE.

The authors declare no conflict of interest.

\# These authors contributed equally to this work.

\section{MATERIALS AND METHODS}

Enzymes and Substrates Human leukocyte elastase (EC 3.4.21.37), $\alpha$-chymotrypsin (EC 3.4.21.1), trypsin (bovine pancreatic type III, EC 3.4.21.4) and thrombin (EC 3.4.21.5), and their substrates $N$-MeO-Suc-Ala-Ala-Pro-Val-pNA (M-4765), Suc-Ala-Ala-Pro-Phe- $p$ NA (S7388), Bz-Ile-Glu-Gly-Arg- $p$ NA (B4875) and $N$-Benzoyl-Phe-Val-Arg- $p$-nitroanilide hydrochloride hydrate (B7632) were all purchased from Sigma.

Fungal Strain and Fermentation The fungal strain was isolated from a soil sample collected in Yunnan Province, P.R. of China and was cultured on slants of potato dextrose agar (PDA) at $25^{\circ} \mathrm{C}$ for $10 \mathrm{~d}$. The agar plugs were inoculated in $500 \mathrm{~mL}$ Erlenmeyer flasks containing $80 \mathrm{~mL}$ of seed media (2.0\% starch, $1.0 \%$ glucose, $0.6 \%$ malt extract, $0.3 \%$ yeast extract, $0.2 \%$ hot-pressed soybean cake meal, $0.2 \% \mathrm{NaCl}$, $0.1 \% \mathrm{MgSO}_{4} \cdot 7 \mathrm{H}_{2} \mathrm{O}$, and $0.2 \% \mathrm{CaCO}_{3}$, final $\mathrm{pH} 7.0$ before sterilization), and the flask cultures were incubated at $27^{\circ} \mathrm{C}$ on a rotary shaker at $220 \mathrm{rpm}$ for $3 \mathrm{~d}$. Twenty $1000 \mathrm{~mL}$ Fernbach flasks, each containing $150 \mathrm{~g}$ of solid media (97.5\% rice, $2.5 \%$ hot-pressed soybean cake meal) were individually inoculated with $1.5 \mathrm{~mL}$ of the seed culture and fermented at $27^{\circ} \mathrm{C}$ under static conditions for $14 \mathrm{~d}$.

Isolation and Determination of Compounds The fermented rice substrate $(1.8 \mathrm{~kg})$ was extracted with $90 \%$ ethanol (3.6L), and the organic solvent was evaporated under vacuum to give slurry. The slurry was centrifuged to separate the precipitate. And the precipitate was dissolved into $5 \mathrm{~mL}$ methanol and subjected to a Sephadex LH-20 column $(2.6 \times 60 \mathrm{~cm})$. The column was eluted with methanol and the active fractions $(1.3 \mathrm{~g})$ were collected. Further purification was performed by medium pressure ODS (Merck Co., 30-40 $\mu \mathrm{m}, 100 \AA$ ) chromatography and three active pure compounds $\mathbf{1}$ (200.0 mg), 2 (25.0 mg) and 3 (426.0 mg) were obtained. Their ${ }^{1} \mathrm{H}-,{ }^{13} \mathrm{C}-\mathrm{NMR}$ spectra were recorded on a Bruker AV-500 NMR spectrometer with tetramethylsilane (TMS) as internal standard. MS spectral data were obtained on a Waters Xevo TQ spectrometer for electrospray ionization (ESI)-MS. Based on ESI-MS, ${ }^{1} \mathrm{H}-$, ${ }^{13} \mathrm{C}$ - and $2 \mathrm{D}-\mathrm{NMR}$ spectroscopic data analysis, they were identified to be nordivaricatic acid, ${ }^{17)}$ divarinyl divarate, ${ }^{18)}$ and 
<smiles>C[B]Cc1cc(OC(=O)c2c(O)cc(O)cc2CCC)cc(O)c1C(=O)O</smiles><smiles>CCCc1cc(O)cc(O)c1C(=O)Oc1[12c-][14c](O)[14cH][14cH][14c]1CCC</smiles><smiles>CCCc1cc(O)cc(O)c1C(=O)Oc1cc(O)c(C(=O)Oc2cc(O)c([13C](=O)O)c([123I])[12c-]2)c(CCC)c1</smiles>

3

Fig. 1. Chemical Structures of Three Depsides

Nordivaricatic acid (1), divarinyl divarate (2), trivaric acid (3).

trivaric acid, ${ }^{19)}$ respectively (Fig. 1). Their assignments of ${ }^{1} \mathrm{H}$ and ${ }^{13} \mathrm{C}$-NMR data were given below.

Nordivaricatic Acid (1): White amorphous powder. ESIMS: $373[\mathrm{M}-\mathrm{H}]^{-}$. ${ }^{1} \mathrm{H}-\mathrm{NMR}\left(500 \mathrm{MHz}\right.$, acetone- $\left.d_{6}\right) \delta: 6.80$ $\left(1 \mathrm{H}, \mathrm{d}, J=2.4 \mathrm{~Hz}, \mathrm{H}-3^{\prime}\right), 6.77\left(1 \mathrm{H}, \mathrm{d}, J=2.4 \mathrm{~Hz}, \mathrm{H}-5^{\prime}\right), 6.42$ $(1 \mathrm{H}, \mathrm{d}, J=2.4 \mathrm{~Hz}, \mathrm{H}-5), 6.33(1 \mathrm{H}, \mathrm{d}, J=2.4 \mathrm{~Hz}, \mathrm{H}-3), 3.02(2 \mathrm{H}$, t, $\left.\left.J=7.5 \mathrm{~Hz}, \mathrm{H}_{-1}\right)^{\prime}\right), 2.94(2 \mathrm{H}, \mathrm{t}, J=7.5 \mathrm{~Hz}, \mathrm{H}-7), 1.71(2 \mathrm{H}, \mathrm{m}$, H-8), 1.68 (2H, m, H-8'), 0.98 (3H, t, J=7.4 Hz, H-9'), 0.96 $(3 \mathrm{H}, \mathrm{t}, J=7.5 \mathrm{~Hz}, \mathrm{H}-9) ;{ }^{13} \mathrm{C}-\mathrm{NMR}\left(125 \mathrm{MHz}\right.$, acetone- $\left.d_{6}\right) \delta$ : $172.0\left(\mathrm{C}-10^{\prime}\right), 168.8$ (C-10), 165.2 (C-2), 163.8 (C-2'), 162.7 (C-4), 153.9 (C-4'), 148.1 (C-6), 147.9 (C-6'), 115.5 (C-5'), 111.2 (C-5), $110.1\left(\mathrm{C}-1^{\prime}\right), 108.2$ (C-3'), 103.4 (C-1), 100.8 (C-3), 38.3 (C-7), 37.6 (C-7'), 24.8 (C-8), 24.6 (C-8'), 13.4 (C-9), 13.3 $\left(\mathrm{C}-9^{\prime}\right)$

Divarinyl Divarate (2): White amorphous powder. ESI-MS: $329[\mathrm{M}-\mathrm{H}]^{-} .{ }^{1} \mathrm{H}-\mathrm{NMR}\left(500 \mathrm{MHz}\right.$, acetone- $\left.d_{6}\right) \delta: 6.66(1 \mathrm{H}, \mathrm{t}$, $\left.J=1.8 \mathrm{~Hz}, \mathrm{H}-5^{\prime}\right), 6.60\left(2 \mathrm{H}, \mathrm{t}, J=1.8 \mathrm{~Hz}, \mathrm{H}-1^{\prime}, \mathrm{H}-3^{\prime}\right), 6.40(1 \mathrm{H}$, d, $J=2.5 \mathrm{~Hz}, \mathrm{H}-5), 6.32(1 \mathrm{H}, \mathrm{d}, J=2.5 \mathrm{~Hz}, \mathrm{H}-3), 2.95(2 \mathrm{H}, \mathrm{m}$, H-7'), 2.57 (2H, m, H-7), 1.70 (2H, m, H-8, H-8'), 1.64 (2H, m, $\left.\mathrm{H}-8, \mathrm{H}-8^{\prime}\right), 0.95$ (3H, t, $\left.J=7.4 \mathrm{~Hz}, \mathrm{H}-9^{\prime}\right), 0.94(3 \mathrm{H}, \mathrm{t}, J=7.5 \mathrm{~Hz}$, $\mathrm{H}-9) ;{ }^{13} \mathrm{C}-\mathrm{NMR}\left(125 \mathrm{MHz}\right.$, acetone- $\left.d_{6}\right) \delta: 170.6(\mathrm{C}-10), 166.2$ (C-4), 163.6 (C-2), 158.9 (C-2'), 151.9 (C-4'), 149.1 (C-6), 146.0 (C-6'), $114.0\left(\mathrm{C}-1^{\prime}\right), 113.6\left(\mathrm{C}-5^{\prime}\right), 112.1(\mathrm{C}-5), 107.3\left(\mathrm{C}-3^{\prime}\right)$, 104.6 (C-1), 101.8 (C-3), 39.4 (C-7), 38.4 (C-7'), 26.0 (C-8), 24.9 (C-8'), 14.0 (C-9), 14.5 (C-9').

Trivaric Acid (3): White amorphous powder. ESI-MS: 551 $[\mathrm{M}-\mathrm{H}]^{-}$. ${ }^{1} \mathrm{H}-\mathrm{NMR}\left(500 \mathrm{MHz}\right.$, acetone- $\left.d_{6}\right) \delta: 11.83(1 \mathrm{H}, \mathrm{s}$, 2"-OH), 11.09 (1H, s, 2-OH), $10.37\left(1 \mathrm{H}, \mathrm{s}, 2^{\prime}-\mathrm{OH}\right), 6.86(1 \mathrm{H}$, d, $\left.J=2.4 \mathrm{~Hz}, \mathrm{H}-3^{\prime}\right), 6.84\left(1 \mathrm{H}, \mathrm{d}, J=2.4 \mathrm{~Hz}, \mathrm{H}-5^{\prime}\right), 6.81(1 \mathrm{H}$, d, $\left.J=2.4 \mathrm{~Hz}, \mathrm{H}-3^{\prime \prime}\right), 6.78\left(1 \mathrm{H}, \mathrm{d}, J=2.4 \mathrm{~Hz}, \mathrm{H}-5^{\prime \prime}\right), 6.40(1 \mathrm{H}$, d, $J=2.4 \mathrm{~Hz}, \mathrm{H}-5), 6.31(1 \mathrm{H}, \mathrm{d}, J=2.4 \mathrm{~Hz}, \mathrm{H}-3), 3.01(2 \mathrm{H}$, t, $\left.J=7.7 \mathrm{~Hz}, \mathrm{H}-7^{\prime \prime}\right), 2.92\left(4 \mathrm{H}, \mathrm{m}, \mathrm{H}-7, \mathrm{H}-7^{\prime}\right), 1.77-1.63(6 \mathrm{H}$, m, H-8, H-8', H-8"), 0.98 (3H, t, $\left.J=7.7 \mathrm{~Hz}, \mathrm{H}-9^{\prime}\right), 0.97(3 \mathrm{H}$, t, $\left.J=7.7 \mathrm{~Hz}, \mathrm{H}-9^{\prime \prime}\right), 0.95(3 \mathrm{H}, \mathrm{t}, J=7.7 \mathrm{~Hz}, \mathrm{H}-9) ;{ }^{13} \mathrm{C}-\mathrm{NMR}$ $\left(125 \mathrm{MHz}\right.$, acetone- $\left.d_{6}\right) \delta$ : $173.2\left(\mathrm{C}-10^{\prime \prime}\right), 170.0\left(\mathrm{C}-10^{\prime}\right), 168.8$ (C-10'), 166.4 (C-2), 165.1 (C-2"), 164.0 (C-4), 161.4 (C-2'), $155.2\left(\mathrm{C}-4^{\prime \prime}\right), 154.4\left(\mathrm{C}-4^{\prime}\right), 149.13$ (C-6), 149.08 (C-6"), 146.7 $\left(\mathrm{C}-6^{\prime}\right), 116.4\left(\mathrm{C}-5^{\prime \prime}\right), 116.2\left(\mathrm{C}-5^{\prime}\right), 114.7\left(\mathrm{C}-1^{\prime}\right), 112.3(\mathrm{C}-5)$, $111.3\left(\mathrm{C}-1^{\prime \prime}\right), 109.2$ (C-3"), 109.0 (C-3'), 104.5 (C-1), 102.0 (C-3), 39.4 (C-7), 38.7 (C-7"), 37.8 (C-7'), 25.9 (C-8)*, 25.7 $\left(\mathrm{C}-8^{\prime \prime}\right)^{*}, 25.5\left(\mathrm{C}-8^{\prime}\right)^{*}, 14.5(\mathrm{C}-9)^{\#}, 14.4\left(\mathrm{C}-9^{\prime \prime}\right)^{\#}, 14.3\left(\mathrm{C}-9^{\prime}\right)^{\#}$.
(*,\#: Assignments can be interchanged.)

Enzyme Activity Assay The activity of human leukocyte elastase was measured according to the previous method, ${ }^{20)}$ with minor modification. Briefly, $50 \mu \mathrm{L}$ reaction buffer $(N-$ (2-hydroxyethyl)piperazine- $N^{\prime}$-2-ethanesulfonic acid (HEPES) $\mathrm{pH} 6.5,0.5 \mathrm{M} \mathrm{NaCl}$ ) containing 0.0015 unit HLE (one unit will release one nanomole of $p$-nitrophenol per second from BOC-L-alanine $p$-nitrophenyl ester at $\mathrm{pH} 6.5$ at $37^{\circ} \mathrm{C}$ ) was incubated with $2 \mu \mathrm{L}$ test compounds (dissolved in dimethyl sulfoxide (DMSO)) or DMSO (as blank control) in 96-well plate at room temperature for $15 \mathrm{~min}$, the reaction was started by addition of $50 \mu \mathrm{L}$ substrate solution containing a $300 \mu \mathrm{M}$ final concentration of $N$-MeO-Suc-Ala-Ala-Pro-Val- $p$ NA. After incubation at $37^{\circ} \mathrm{C}$ for $30 \mathrm{~min}$, the hydrolysis product of $p$-nitroaniline was measured by the optical density (OD) at $405 \mathrm{~nm}$ using a microplate reader (Wallac 1420 Victor $^{2}$, Perkin-Elmer). Ulinastatin, a kind of broad-spectrum protease inhibitor, was purchased from Guangdong Biochemistry Medicine Corporation of China as positive control. Its specific activity is $1666 \mathrm{U} / \mathrm{mg}$ protein, 1 unit being the amount necessary to inhibit the activity of $2 \mu \mathrm{g}$ trypsin by $50 \%$.

The activities of $\alpha$-chymotrypsin, trypsin and thrombin were assayed with the same precedures as that of HLE, except for using $200 \mu \mathrm{M}$ Suc-Ala-Ala-Pro-Phe- $p$ NA, $300 \mu \mathrm{M}$ Bz-IleGlu-Gly-Arg- $p$ NA, and $300 \mu \mathrm{M} \quad N$-Benzoyl-Phe-Val-Arg- $p$ nitroanilide hydrochloride hydrate as substrates, respectively, and the buffer used was $0.05 \mathrm{M}$ Tris- $\mathrm{HCl}$ containing $0.15 \mathrm{M}$ $\mathrm{NaCl}, \mathrm{pH} 7.2$.

$\mathrm{IC}_{50}$ value, the half maximal inhibitory concentration, was determined from the logarithmic regression line of a dose-response curve. All experiments were undertaken in triplicate and repeated at least three times. Data are presented as average values.

Kinetics Study Kinetic experiments were conducted as described. ${ }^{21)}$ Reversible or irreversible inhibition mode is distinguished by the first-order enzyme-catalyzed reactions, which were performed at $300 \mu \mathrm{M} N$-MeO-Suc-Ala-Ala-ProVal- $p$ NA substate, three different concentration inhibitor, and HLE with increasing concentration. Lineweaver-Burk double reciprocal plot of $1 / v$ versus $1 /[S]$ was made by the velocities of enzyme reactions that were carried out at a variety of 
A

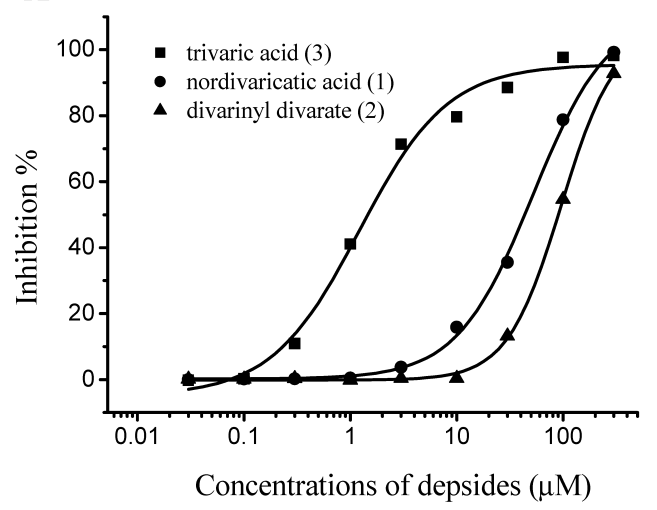

C

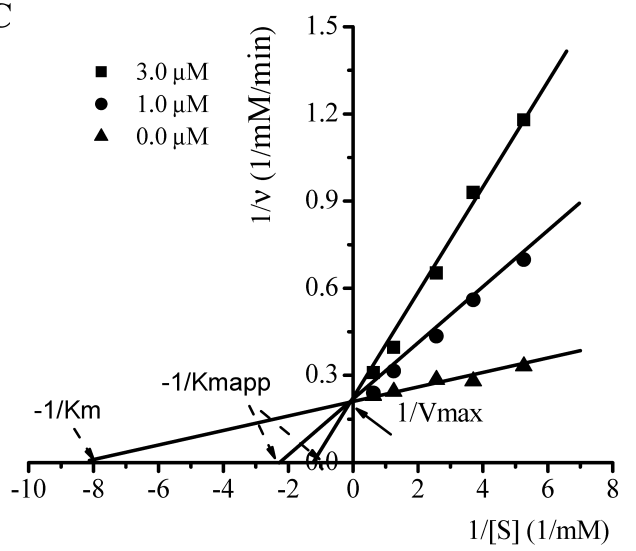

B

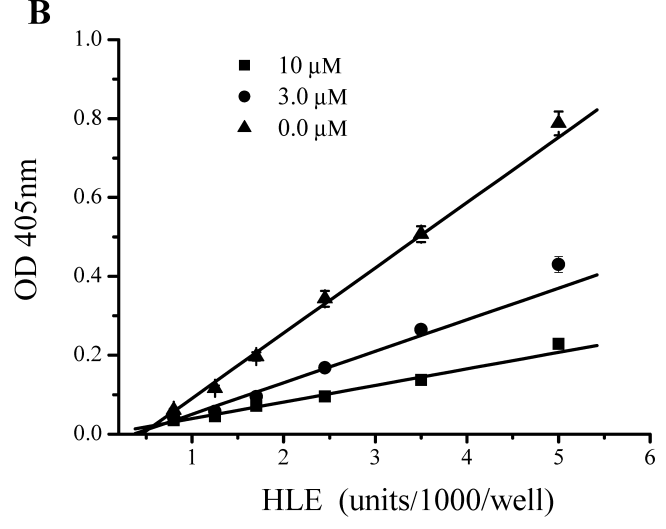

D

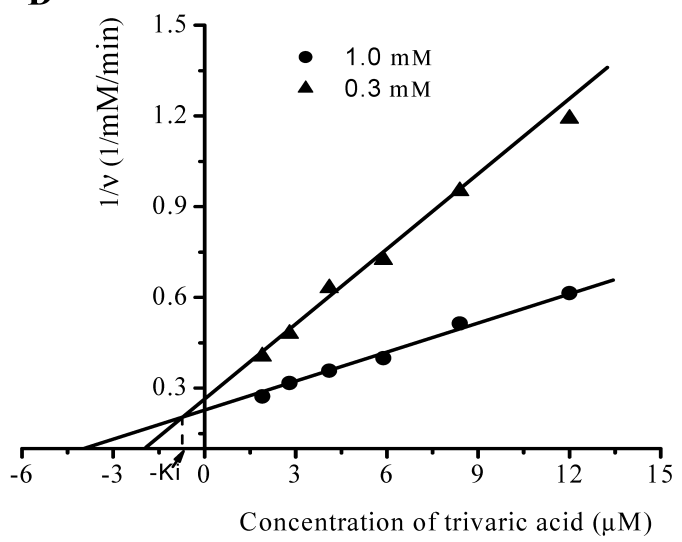

Fig. 2. Inhibitory Curves of Depsides against HLE and Inhibitory Kinetics of Trivaric Acid on HLE

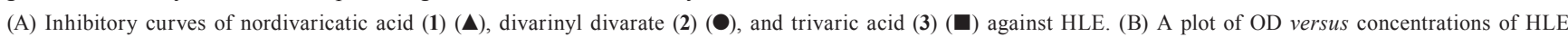
in presence of three different trivaric acid concentrations of $0.0 \mu \mathrm{M}(\mathbf{\Delta}), 3.0 \mu \mathrm{M}(\mathbf{O})$, or $10 \mu \mathrm{M}(\mathbf{\square})$. (C) Lineweaver-Burk plot of 1/v versus $1 /[S]$ for inhibition of HLE by $0.0 \mu \mathrm{m}(\boldsymbol{\Delta}), 1.0 \mu \mathrm{M}(\boldsymbol{\Theta})$ or $3.0 \mu \mathrm{M}(\mathbf{\square})$ trivaric acid. (D) Dixon plot of $1 / v$ versus $[I]$ for HLE inhibitor trivaric acid at two substrate concentrations of $0.3 \mathrm{~mm}(\boldsymbol{\Delta})$ and $1.0 \mathrm{~mm}$ (). Data are mean values of triplicate experiments.

substrate concentrations $(0.1-1.0 \mathrm{~mm})$ and 0.0015 unit HLE in the presence or absence of the inhibitor, where the Michaelis constant $K_{\mathrm{m}}$ (concentration of substrate that produces halfmaximal velocity) and apparent $K_{\mathrm{m}}\left(K_{\mathrm{mapp}}, K_{\mathrm{m}}\right.$ in the presence of an inhibitor) were obtained from the curve. Dixon plot of $1 / v$ versus $[I]$ (concentration of inhibitor) was made by the linearisations of the rates of enzyme reactions performed at a dilution serial of concentrations of inhibitor and three different substrate concentrations $(0.0,0.3,1.0 \mathrm{~mm})$.

\section{RESULTS}

Inhibitory Activity against HLE Inhibitory effects of the depsides against HLE were tested with $N$-MeO-Suc-AlaAla-Pro-Val- $p$ NA as the substrate. The didepsides, nordivaricatic acid (1) and divarinyl divarate (2) could weakly inhibit HLE with the $\mathrm{IC}_{50}$ values of $45.1 \mu \mathrm{M}$ and $92.6 \mu \mathrm{M}$, respectively. Trivaric acid (3), one tridepside, exhibited high inhibitory activity toward HLE with $\mathrm{IC}_{50}$ value of $1.8 \mu \mathrm{M}$ (Fig. 2A), its inhibitory potency toward HLE is approximately 25-50-folds over that of two didepsides. Ulinastatin, a positive control in the assay, exhibited an $\mathrm{IC}_{50}$ value of $1.1 \mu \mathrm{g} / \mathrm{mL}(1.8 \mathrm{U} / \mathrm{mL})$.

Inhibitory Specificity To determine the specificity of these depsides on serine protease, their inhibitory effects toward $\alpha$-chymotrypsin, trypsin and thrombin was also investigated. Studies showed that they did not exhibit inhibitory activity against these serine proteases here mentioned even at $150 \mu \mathrm{M}$. Trivaric acid (3) displayed a more than 83-fold selectivity for HLE over some serine protease, suggesting trivaric acid is a potent and selective HLE inhibitor.

Inhibitory Kinetics on HLE To further elucidate the action mechanism of trivaric acid (3) toward HLE, the inhibition kinetics was further investigated. Firstly, the reversible or irreversible inhibition was distinguished by a plot of OD versus $[E]$, which was obtained from enzyme reactions carried out with a dilution series of HLE enzyme $(0.005,0.0035,0.00245$, $0.0017,0.00125,0.00086 \mathrm{U}$ per well) and three different concentrations of trivaric acid $(10.0,3.0,0.0 \mu \mathrm{M})$. As shown in Fig. $2 \mathrm{~B}$, the velocity of enzyme reaction was increased with increasing concentration of enzyme. In present of trivaric acid, the reaction rate was decreased with the concentration of trivaric acid, and remained a linear relationship with enzyme concentration, indicting the inhibition mode of trivaric acid is reversible.

Next, a Lineweaver-Burk double reciprocal plot of $1 / v$ versus $1 /[S]$ was performed by the enzyme reactions which were carried out at a serial dilution of $N$-MeO-Suc-Ala-Ala-ProVal- $p$ NA substrate concentrations in the range of $0.1-1.0 \mathrm{~mm}$ in the presence of three different concentrations of trivaric acid $(0.0,1.0,3.0 \mu \mathrm{M})$. As the plot (Fig. 2C) shown, the $K_{\mathrm{m}}$ of HLE is about $125 \mu \mathrm{M}$, the $K_{\mathrm{mapp}}$ were about $371 \mu \mathrm{M}$ and $769 \mu \mathrm{M}$ at the presence of $1.0 \mu \mathrm{M}$ or $3.0 \mu \mathrm{M}$ trivaric acid, respectively. 
The $K_{\text {mapp }}$ is increased with increasing trivaric acid concentration, whereas the maximum velocity $\left(V_{\max }\right)$ of the enzyme reaction apparently remained unchanged, indicating that the inhibition mode is typical competitive. By the equation of $K_{\text {mapp }}=K_{\mathrm{m}}\left(1+[I] / K_{\mathrm{i}}\right),{ }^{21)}$ the inhibition constant $\left(K_{\mathrm{i}}\right)$ value of trivaric acid is calculated to be about $0.55 \mu \mathrm{M}$, which is consistent with the $K_{\mathrm{i}}$ value of $0.68 \mu \mathrm{M}$ obtained from the Dixon plot of $1 / v$ versus $[I]$ (Fig. 2D) which was made at a dilution serial of concentrations of inhibitor and two substrate concentrations $(0.3,1.0 \mathrm{~mm})$.

\section{DISCUSSION}

Nature is also the most valuable source of potential lead structures for drug development. So far, a significant number of natural products have been identified as HNE inhibitors with micromolar ranges of activity. ${ }^{12,13)}$ Melzig et al. reported various phenolic compounds as HLE inhibitors, including flavones, cinnamic acid depside derivatives and caffeic acid derivatives. $^{20)}$ Löser et al. reported that fukinolic acid, one of depside derivatives from Cimicifuga racemosa, could significantly inhibit $\mathrm{HNE}$ with an $\mathrm{IC}_{50}$ of $0.23 \mu \mathrm{M}^{22)}$ Depside is a type of polyphenolic compounds composed of two or more monocyclic aromatic units linked by an ester bond. Depsides are most often found in lichens, ${ }^{23,24)}$ but have also been isolated from high plants ${ }^{25,26)}$ and marine or endophytic fungi. ${ }^{27,28)}$ Nordivaricatic acid (1), divarinyl divarate (2), and trivaric acid (3) were all originally isolated from lichens. ${ }^{17-19)}$ In the present study, the three depsides, for the first time, are isolated from a soil derived fungal strain.

Depsides have been reported to have a variety of pharmacological activities such as antibiotic, anti-human immunodeficiency virus (HIV), antioxidative. ${ }^{29-31)}$ However, there is little bioactivity information reported on nordivaricatic acid (1), divarinyl divarate (2), and trivaric acid (3). In the present study, the three phenolic depsides were discovered as inhibitors of HLE, especially tridepside trivaric acid (3) was demonstrated to be a high potent, selective, and reversible competitive HLE inhibitor.

Acknowledgments This work was supported by the National Natural Science Foundation of China (Grant Number 81173137) and the State Key New Drug Creation and Manufacturing Program (2010ZX09401-403, 2011ZX09401-306, 2012ZX09301002-003).

\section{REFERENCES}

1) Pham CT. Neutrophil serine proteases: specific regulators of inflammation. Nat. Rev. Immunol., 6, 541-550 (2006).

2) Heutinck KM, ten Berge IJM, Hack CE, Hamann J, Rowshani AT. Serine proteases of the human immune system in health and disease. Mol. Immunol., 47, 1943-1955 (2010).

3) Greene CM, McElvaney NG. Proteases and antiproteases in chronic neutrophilic lung disease-relevance to drug discovery. $\mathrm{Br}$. J. Pharmacol., 158, 1048-1058 (2009).

4) Fujie K, Shinguh Y, Yamazaki A, Hatanaka H, Okamoto M, Okuhara M. Inhibition of elastase-induced acute inflammation and pulmonary emphysema in hamsters by a novel neutrophil elastase inhibitor FR901277. Inflamm. Res., 48, 160-167 (1999).

5) Wang Z, Chen F, Zhai R, Zhang L, Su L, Lin X, Thompson T, Christiani DC. Plasma neutrophil elastase and elafin imbalance is associated with acute respiratory distress syndrome (ARDS) development. PLoS ONE, 4, e4380 (2009).

6) Guay C, Laviolette M, Tremblay GM. Targeting serine proteases in asthma. Curr. Top. Med. Chem., 6, 393-402 (2006).

7) Ohbayashi H. Neutrophil elastase inhibitors as treatment for COPD. Expert Opin. Investig. Drugs, 11, 965-980 (2002).

8) Lucas SD, Costa E, Guedes RC, Moreira R. Targeting COPD: Advances on low-molecular-weight inhibitors of human neutrophil elastase. Research Reviews, 2011, article first published online 〈doi:10.1002/med.20247》.

9) Watanabe H, Hattori S, Katsuda S, Nakanishi I, Nagai Y. Human neutrophil elastase: degradation of basement membrane components and immunolocalization in the tissue. J. Biochem., 108, 753-759 (1990).

10) Kawabata $K$, Hagio $T$, Matsuoka $S$. The role of neutrophil elastase in acute lung injury. Eur. J. Pharmacol., 451, 1-10 (2002).

11) Sato T, Takahashi S, Mizumoto $T$, Harao M, Akizuki M, Takasugi M, Fukutomi T, Yamashita J. Neutrophil elastase and cancer. Surg. Oncol., 15, 217-222 (2006).

12) Ohbayashi H. Current synthetic inhibitors of human neutrophil elastase in 2005. Expert Opin. Ther. Pat., 15, 759-771 (2005).

13) Siedle B, Hrenn A, Merfort I. Natural compounds as inhibitors of human neutrophil elastase. Planta Med., 73, 401-420 (2007).

14) Nakayama $Y$, Odagaki $Y$, Fujita $S$, Matsuoka S, Hamanaka N, Nakai H, Toda M. Clarification of mechanism of human sputum elastase inhibition by a new inhibitor, ONO-5046, using electrospray ionization mass spectrometry. Bioorg. Med. Chem. Lett., 12, 2349-2353 (2002).

15) Iwata K, Doi A, Ohji G, Oka H, Oba Y, Takimoto K, Igarashi W, Gremillion DH, Shimada T. Effect of neutrophil elastase inhibitor (sivelestat sodium) in the treatment of acute lung injury (ALI) and acute respiratory distress syndrome (ARDS): a systematic review and meta-analysis. Intern. Med., 49, 2423-2432 (2010).

16) Luisetti M, Sturani C, Sella D, Madonini E, Galavotti V, Bruno G, Peona V, Kucich U, Dagnino G, Rosenbloom J, Starcher B, Grassi C. MR889, a neutrophil elastase inhibitor, in patients with chronic obstructive pulmonary disease: a double-blind, randomized, placebo-controlled clinical trial. Eur. Respir. J., 9, 1482-1486 (1996).

17) Elix JA, Tearne PD. Nordivaricatic acid, a new depside from the lichen Heterodea beaugleholei. Aust. J. Chem., 30, 2333-2335 (1977).

18) Elix JA, Wardlaw JH. New depsides from the lichen Neofuscelia depsidella. Aust. J. Chem., 50, 1145-1150 (1997).

19) Culberson CF, La Greca S, Johnson A, Culberson WL. Trivaric acid, a new tridepside in the Ramalina americana chemotype complex (lichenized Ascomycota: Ramalinaceae). Bryologist, 102, 595-601 (1999).

20) Melzig MF, Löser B, Ciesielski S. Inhibition of neutrophil elastase activity by phenolic compounds from plants. Pharmazie, 56, 967-970 (2001).

21) Eisenthal R, Danson MJ. Enzyme assays: a practical approach. Oxford University Press (2002).

22) Löser B, Kruse SO, Melzig MF, Nahrstedt A. Inhibition of neutrophil elastase activity by cinnamic acid derivatives from Cimicifuga racemosa. Planta Med., 66, 751-753 (2000).

23) Müller K. Pharmaceutically relevant metabolites from lichens. Appl. Microbiol. Biotechnol., 56, 9-16 (2001).

24) Shukla V, Joshi GP, Rawat MSM. Lichens as a potential natural source of bioactive compounds: a review. Phytochem. Rev., 9, 303-314 (2010).

25) Hillenbrand M, Zapp J, Becker H. Depsides from the petals of $\mathrm{Pa}$ paver rhoeas. Planta Med., 70, 380-382 (2004).

26) Reynertson KA, Wallace AM, Adachi S, Gil RR, Yang H, Basile MJ, D’Armiento J, Weinstein IB, Kennelly EJ. Bioactive depsides and anthocyanins from jaboticaba (Myrciaria cauliflora). J. Nat. Prod., 69, 1228-1230 (2006)

27) Nielsen J, Nielsen PH, Frisvad JC. Fungal depside, guisinol, from 
a marine derived strain of Emericella unguis. Phytochemistry, 50, 263-265 (1999).

28) Nazir M, Sultan M, Riaz N, Hafeez M, Hussain H, Ahmed I, Schulz B, Draeger S, Jabbar A, Krohn K, Ashraf M, Saleem M. Depsitinuside: a new depside galactoside from an endophytic fungus isolated from Viburnum tinus. J. Asian Nat. Prod. Res., 13, 1056-1060 (2011).

29) Schmeda-Hirschmann G, Tapia A, Lima B, Pertino M, Sortino M, Zacchino S, Arias AR, Feresin GE. A new antifungal and antiprotozoal depside from the Andean lichen Protousnea poeppigii. Phytother. Res., 22, 349-355 (2008).

30) Neamati N, Hong H, Mazumder A, Wang S, Sunder S, Nicklaus MC, Milne GW, Proksa B, Pommier Y. Depsides and depsidones as inhibitors of HIV-1 integrase: discovery of novel inhibitors through 3D database searching. J. Med. Chem., 40, 942-951 (1997).

31) Hidalgo ME, Fernández E, Quilhot W, Lissi E. Antioxidant activity of depsides and depsidones. Phytochemistry, 37, 1585-1587 (1994). 